\title{
Sleep is an auto-regulatory global phenomenon
}

\section{Velayudhan Mohan Kumar*}

Comprehensive Center for Sleep Disorders, Biomedical Technology Wing, Sree Chitra Tirunal Institute for Medical Sciences and Technology, Thiruvananthapuram, India

*Correspondence: wfsrs2005@rediffmail.com

Sleep occurring passively due to decreased activity of the brainstem reticular formation was the dominant belief during the 1940s and 1950s (Bremer, 1938; Moruzzi and Magoun, 1949). Some experimental findings, even at that time, suggested that some of the brain regions are capable of producing sleep actively (Hess, 1932; Nauta, 1946). Though these findings questioned the passive sleep theory, the discovery of REM sleep in the 1950s by Kleitman and colleagues (Aserinsky and Kleitman, 1953; Dement and Kleitman, 1957) and "paradoxical sleep" by Jouvet et al. (1959) marked the beginning of the era of the active sleep genesis concept. The years that followed saw the dominance of active sleep genesis theory and it even overshadowed the very idea that almost all the brain regions have the inherent capacity to swing between the states of sleep and wakefulness. There is now growing evidence to suggest that sleep is auto-regulatory and that it is not necessary to attribute sleep genesis to either an active or a passive mechanism (Kumar, 2009, 2010).

Behavioral observations, and electrophysiological signals produced by the brain regions below and above the transection of the brain in experimental studies, showed that almost every part of the brain has the inherent ability to show sleep-wake oscillation (Villablanca, 1965). This may be considered as some of the earliest evidence in support of global nature of sleep regulation and auto-regulatory capacity of every brain region for sleep genesis, even though these eminent scientists who conducted the transection studies never made such a claim. Even the common clinical observations where sleep re-emerges after strokes do also support the global auto-regulatory nature of sleep. There is no instance in which there was complete insomnia following acute brain lesions. Several experimental studies have identified tiny regions in the preoptic area responsible for non-REM sleep promotion (John et al., 1994; John and Kumar, 1998; Lu et al., 2000; Ray et al., 2005). But it is impossible to abolish sleep totally in any animal, even after large lesions in the above-mentioned areas. These findings suggest that sleep is a robust fundamental self-organizing global property that is not restricted to any small group of neurons. It perhaps may be nature's ingenious way to provide alternate pathways in the brain so that a crucial function like sleep is not compromised even in the most extreme circumstances (Gulia, 2012).

Way back Kristiansen and Courtois (1949) demonstrated that isolated cerebral cortical tissues, can show waxing and waning local field potentials. More recent studies have also shown that the cortical columns oscillate between awake-like and sleep-like states (Krueger et al., 2008). It was even proposed that individual cells sleep independently of other cells. According to Llinás and Steriade (2006) thalamic neurons have the intrinsic electrical properties that govern natural functional states such as sleep and vigilance. More recently a novel mechanism for sleep-wake control, based on gamma band activity, was described. It supports the global nature of sleep-wake oscillation that is orchestrated by brainstem-thalamic mechanism, and questions the undue importance given to the hypothalamus for the regulation of sleep-wakefulness (Urbano et al., 2012). From the evolutionary point of view it can be assumed that the primitive brain had auto-regulatory oscillations between awake-like and sleep-like states (Cirelli, 2009). As evolution progressed, and as the brainstem, diencephalon, and neocortex were formed, they also became part of the oscillating network. Prior activity in the network determines the probability of the network entering the sleep-like state or awake-like state (Krueger et al., 2008).

Hess had shown in the 1930s that the same locus in the thalamus can produce sleep-like and awake-like activity by varying the frequency of stimulation. Chemical stimulation studies have shown that either sleep or wakefulness could be elicited from the same loci by application of different neurotransmitters. Even the same transmitter under different experimental conditions can produce opposing responses (Kumar, 2005; Kumar et al., 2006, 2007). These findings question the very idea of assigning a sleep regulatory role to any one particular brain region. There are external and internal factors that influence the swing of sleep-wakefulness toward either sleep or wake state. There are several internal signals, including sleep inducing substances, which are sleep facilitating. It was suggested that the auto-regulatory/auto-modulatory characteristic of sleep and/or its homeostatic part operate through adenosine and other sleep regulatory substances (Manzar and Hussain, 2012). Basal forebrain and hypothalamus should be considered as part of the neural mechanism through which many of these internal signals act. These brain regions integrate sleep with body temperature, hunger, thirst, circadian cycles, neuroendocrine outputs, homeostatic mechanisms, autonomic responses, and stereotyped behaviors (Kumar, 2005). There is growing evidence to show that the thermoregulatory system is part of the global homeostatic sleep regulatory mechanism (Mallick and Kumar, 2012). The research on the effects of exercise on sleep have provided enough evidences to conclude that the auto-regulatory, global regulation of sleep is not the exclusive domain of the central nervous system, but it is heavily influenced by inputs from the rest of the body (Uchida et al., 2012). Even meditation practices influence brain functions, modulate autonomic, metabolic, endocrine, and immune functions, and thus mediate global regulatory changes in various behavioral states including sleep (Nagendra et al., 2012).

It can be concluded that normal sleep is an auto-regulated global phenomenon. Sleep and vigilance emerge from the dynamic interaction of neuronal network throughout the brain. The tendency for sleep-wake oscillation is derived from a collective response of the several hundreds of neurons with oscillating membrane potential.

\section{REFERENCES}

Aserinsky, E., and Kleitman, N. (1953). Regularly occurring periods of eye motility and concomitant phenomena during sleep. Science 118, 273-274.

Bremer, F. (1938). L'activité électrique de l'écorce cerebral etle probléme physiologique du sommeil. Boll. Soc. Ital. Biol. Sper. 13, 271-270. 
Cirelli, C. (2009). The genetic and molecular regulation of sleep: from fruit flies to humans. Nat. Rev. Neurosci. 10, 549-560.

Dement, W., and Kleitman, N. (1957). The relation of eye movements during sleep to dream activity: an objective method for the study of dreaming. J. Exp. Psychol. $53,339-346$.

Gulia, K. K. (2012). Dynamism in activity of the neural networks in brain is the basis of sleep-wakefulness oscillations. Front. Neur. 3:38. doi: 10.3389/fneur.2012.00038

Hess, W. R. (1932). Beitrage zur Physiologie d. Hirnstammes 1. Die Methodik der lokalisierten Reizung. und Ausschaltung subkortikaler Hirnabschnitte. Leipzig: Georg Thième, 1-122.

John, J., and Kumar,V.M. (1998). Effect of NMDA lesion of the medial preoptic neurons on sleep and other functions. Sleep 21, 587-598.

John, J., Kumar, V. M., Gopinath, G., Ramesh, V., and Mallick, H. N. (1994). Changes in sleep-wakefulness after kainic acid lesion of the preoptic area in rats. Jpn. J. Physiol. 44, 231-242.

Jouvet, M., Michel, F., and Courjon, J. (1959). Sur un stade d'activité é]ectrique cérébrale rapide au cours du sommeil physiologique. C. R. Soc. Biol. (Paris) 153, 1024-1028.

Kristiansen, K., and Courtois, G. (1949). Rhythmic activity from isolated cerebral cortex. Electroencephalogr. Clin. Neurophysiol. 1, 265-272.

Krueger, J. M., Rector, D. M., Roy, S., van Dongen, H. P., Belenky, G., and Panksepp, J. (2008). Sleep as a fundamental property of neuronal assemblies. Nat. Rev. Neurosci. 9, 910-919.

Kumar, V. M. (2005). Body temperature and sleep: are they controlled by the same mechanism? Sleep Biol. Rhythms 2, 103-124.

Kumar, V. M. (2009). Neural regulation of sleep: a global phenomenon. Sleep Biol. Rhythms 7, A35.

Kumar, V. M. (2010). Sleep is neither a passive nor an active phenomenon. Sleep Biol. Rhythms 8, 163-169.

Kumar, V. M., Vetrivelan, R., and Mallick, H. N. (2006). Alpha-1 adrenergic receptors in the medial preoptic area are involved in the induction of sleep. Neurochem. Res. 31, 1095-1102.

Kumar, V. M., Vetrivelan, R., and Mallick, H. N. (2007). Noradrenergic afferents and receptors in the medial preoptic area: neuroanatomical and neurochemical links between the regulation of sleep and body temperature. Neurochem. Int. 50, 783-790.
Llinás, R. R., and Steriade, M. (2006). Bursting of thalamic neurons and states of vigilance. J. Neurophysiol. 95, 3297-3308.

Lu, J., Shiromani, P. J., and Saper, C. B. (2000). Effects of lesions of the ventral lateral preoptic nucleus on NREM and REM sleep. J. Neurosci. 20, 3830-3840.

Mallick, H. N., and Kumar, V. M. (2012). Basal forebrain thermoregulatory mechanism modulates auto-regulated sleep. Front. Neur. 3:99. doi: 10.3389/fneur.2012.00099

Manzar,M.D., and Hussain,M.E. (2012).Sleep-immune system interaction: advantages and challenges of human sleep loss model. Front. Neur. 3:2. doi: 10.3389/fneur.2012.00002

Moruzzi, G., and Magoun, H. W. (1949). Brain stem reticular formation and activation of the EEG. Electroencephalogr. Clin. Neurophysiol. 1, 455-473.

Nagendra, R. P., Maruthai, N., and Kutty, B. M. (2012). Meditation and its regulatory role on sleep. Front. Neur. 3:54. doi: 10.3389/fneur.2012.00054

Nauta, W. J.H. (1946). Hypothalamic regulation of sleep in rats. An experimental study. J. Neurophysiol. 9, 285-316.

Ray, B., Mallick, H. N., and Kumar, V. M. (2005). Changes in sleep-wakefulness in the medial preoptic area lesioned rats: role of thermal preference. Behav. Brain Res. $158,43-52$.

Uchida, S., Shioda, K., Morita, Y., Kubota, C., Ganeko, M., and Takeda, N. (2012). Exercise effects on sleep physiology. Front. Neur. 3:48. doi: 10.3389/fneur.2012.00048

Urbano, F. J., Kezunovic, N., Hyde, J., Simon, C., Beck, P., and Garcia-Rill, E. (2012) Gamma band activity in the reticular activating system. Front. Neur. 3:6. doi: 10.3389/ fneur.2012.00006

Villablanca, J. (1965). The electrocorticogram in the chronic "cerveau isole" of the cat. Electroencephalogr. Clin. Neurophysiol. 19, 576-586.

Received: 19 April 2012; accepted: 27 May 2012; published online: 13 June 2012.

Citation: Kumar VM (2012) Sleep is an auto-regulatory global phenomenon. Front. Neur. 3:94. doi: 10.3389/fneur.2012.00094

This article was submitted to Frontiers in Sleep and Chronobiology, a specialty of Frontiers in Neurology.

Copyright (c) 2012 Kumar. This is an open-access article distributed under the terms of the Creative Commons Attribution Non Commercial License, which permits non-commercial use, distribution, and reproduction in other forums, provided the original authors and source are credited. 